\title{
SOME FACTORS AFFECTING THE NEUROTOXIC EFFECT OF PALMYRAH FLOUR
}

\section{By \\ KURUWITA ARACHCHIIE WINIDIKA SUMUDUNIE}

M. Aftilil. 22002 


\section{DECLARATION BY THE CANDIDATE}

"The work described in this thesis was carried out by me under the supervision of Professor E.R. Jansz (Head of the Department, Department of Biochemistry, Faculty of Medical Sciences, University of Sri Jayewardenepura) and Professor S.M.D.N. Wickramasinghe (Department of Biochemistry, Faculty of Medical Sciences, University of Sri Jayewardenepura) and a report on this has not been submitted in whole or in part to any University for another Degree/Diploma"

K. A. Undho Sumudvie

Kuruwita Arachchige Vindika Sumudunie
..2 loglo3.

Date 


\section{DECLARATION OF THE SUPERVISORS}

"We certify that the above statement made by the candidate is true and that this thesis is suitable for submission to the University for the purpose of evaluation."
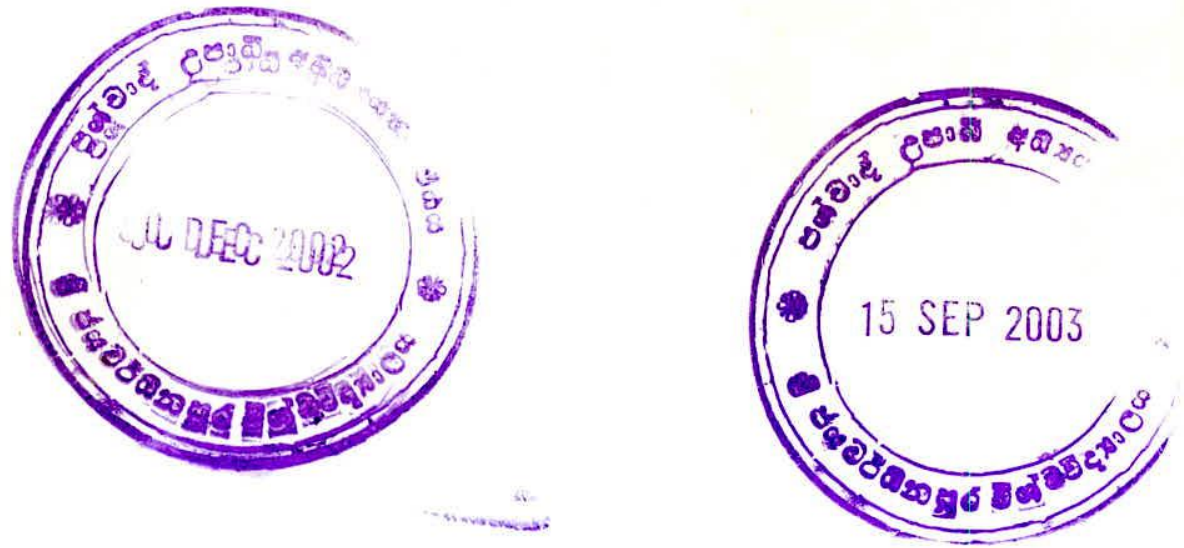

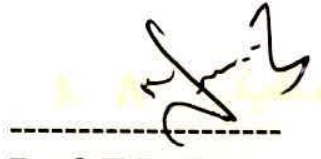

Prof. E.R. Jansz (Supervisor)
S.M.N. Wickamagih

Prof. S.M.D.N. Wickramasinghe (Supervisor) 
SOME FACTORS AFFECTING THE NEUROTOXIC EFFECT OF

PALMYRAH FLOUR

BY

KURUWITA ARACHCHIGE VINDIKA SUMUDUNIE

Thesis submitted to the University of Sri Jayewardenepura for the award of the Degree of Master of Philosophy in Biochemistry on 2002 
TABLE OF CONTENTS

Page No

I. LIST OF TABLES viii

II. LIST OF FIGURES ix

II. LIST OF PLATES $\mathrm{x}$

IV. ABBREVIATIONS xii

V. ACKNOWLEDGMENTS xiv

VI. ABSTRACT $\quad$ xvi

1. INTRODUCTION

1.1 General introduction 1

1.2 Justification and scope of study 5

2. LITERATURE REVIEW

2.1 General description of the palmyrah palm 6

2.2 Distribution of palmyrah palm 6

2.3 Production of palmyrah palm 9

2.4 Source of palmyrah flour 9

$\begin{array}{lll}2.5 & \text { Odiyal flour } & 10\end{array}$

$\begin{array}{lll}2.5 .1 & \text { Composition } & 10\end{array}$

2.5.2 The microelement composition of odiyal flour $\quad 10$

2.5.3 The amino acid composition of odiyal flour $\quad 10$ 
$\begin{array}{ll}2.6 & \text { The products of palmyrah palm } \\ \end{array}$

$\begin{array}{lll}\text { 2.6.1 Palmyrah juice (Sap) } & 15\end{array}$

2.6.2 Toddy and sweet toddy 15

$\begin{array}{lll}2.6 .3 & \text { Timber } & 16\end{array}$

$\begin{array}{lll}2.6 .4 \text { Leaf } & 16\end{array}$

$\begin{array}{lll}2.6 .5 & \text { Fruit } & 16\end{array}$

$\begin{array}{lll}2.6 .6 & \text { Root } & 17\end{array}$

$\begin{array}{lll}\text { 2.6.7 Folk medicine } & 17\end{array}$

2.6.8 The bitterness of palmyrah fruit 18

$\begin{array}{lll}2.6 .9 & \text { Flabelliferins } & 18\end{array}$

$\begin{array}{ll}2.6 .10 \text { Steroids } & 19\end{array}$

$\begin{array}{ll}\text { 2.6.11 Dammaranes } & 19\end{array}$

$\begin{array}{ll}2.6 .12 \cdot \text { Others } & 2.0\end{array}$

$\begin{array}{lll}2.7 & \text { Reported toxicities } & 20\end{array}$

2.7.1 The neurotoxic effect 20

2.7.2 The hepatotoxic effect 23

2.7.3 The immunosuppressive effect 25

$\begin{array}{lll}2.7 .4 & \text { Mutagenic effect } & 27\end{array}$

$\begin{array}{lll}2.7 .5 & \text { Clastrogenic effect } & 27\end{array}$ 


\section{MATERIALS AND METHODS}

3.1 Materials

3.1.1 Water

3.1.2 Solvents

3.1.3 Special chemicals

3.1.4 Enzymes

3.1.5 Animals

3.1.6 Palmyrah flour/ Odiyal/ Plukodiyal

3.1.7 Animal feed

3.2.1 Determination of the components of palmyrah flour

3.2.1(1) Determination of moisture content

3.2.1(ii) Determination of digestible carbohydrate

3.2.1(iii) Determination of the fibre content

3.2.1(iv) Determination of protein content

3.2.1(v) Determination of fat content

3.2.2 Animal model

3.2.3 Separation of neurotoxic principal 
3.2.3(ii) Preparation of extractives for oral administration 47

3.2.3(iii) Medium pressure liquid chromatography (MPLC) 47

3.2.3(iv) Preabsorbing the sample 47

3.2.3(v) Column packing $\quad 48$

3.2.3(vi) Solvent gradients $\quad 50$

3.2.3(vii) Preparation of MPLC fractions for oral 50 administration

3.2.4 Further separation of neurotoxic fraction by 52 Ion-exchange resin

3.2.4(i) Resin desalting $\quad 52$

3.2.4(ii) Purification of resin $\quad 52$

3.2.4(iii) Sample preparation $\quad 52$

3.2.4(iv) Fractionation $\quad 53$

3.2.4(v) Preparation of ion-exchange resin fraction 53 for oral administration

3.2.5 Variation in palmyrah content 53

3.2.5(i) Preparation of $100 \%$ palmyrah feed pellet 53

3.2.5(ii) Preparation of 70\% palmyrah feed pellet $\quad 53$

3.2.5(iii) Preparation of 50\% palmyrah feed pellet $\quad 54$

3.2.6 Variation of Source of palmyrah flour 54

3.2.7 Imitation of traditional methods of cooking 54 
of palmyrah recipes

3.2.7(i) Preparation of "Pittu" from

washed palmyrah flour

3.2.7(ii) Preparation of "Pittu" from non washed

palmyrah flour

3.2.7(iii) Preparation of "Palm Posha" feed pellet

3.2.8 Variation of heat treatment

3.2.9 Studies on species variation

3.2.10 Analysis of parameters

3.2.10(i) Collection of blood and separation of serum 55

3.2.10(ii) Enzyme assays

3.2.11 Statistical analysis

3.2.12 Examination of organs

3.2.13 Histopathological examination

3.2.13 (i) Collection and fixation of tissues

3.2.13(ii) Processing, embedding and cutting of tissues 58

3.2.13(iii) Haematoxylin and Eosin ( $\mathrm{H} \& \mathrm{E})$ staining 58

3.2.13(iv) Oil Red O' method 59

3.2.14 Monitoring of fractions of MPLC 60

3.2.14(i) Thin layer chromatography (Tlc) 60

3.2.14(ii) Preparation of Tlc plates 60

3.2.14(iii) Solvent system 61 


\section{RESULTS}

4.1 Proximate composition of palmyrah flour

4.2.1 Effect of $100 \%, 70 \%$ and $50 \%$ palmyrah feed pellets on Wistar rats

4.2.2 Effect of $50 \%$ palmyrah flour on Wistar rats

4.2.3 Effect of 50\% palmyrah flour on Alanine aminotransferase and Aspartate aminotransferase

4.2.4 Toxicity and locality of collection of palmyrah shoots

4.2.5 Effect of extractives

4.2.6 Chemical studies on extractives

4.4 Treatments of palmyrah flour

palm posha

4.4.3 Effect of dry heat treatment 
4.5 Hitopathological examination of effect of heat treatment

4.6 Toxic effects of water extracts in the rat

4.7. Bioactivity directed separation of toxic fraction

4.7.1 Separation of toxic fraction by MPLC method

4.72 Histopathological examination 80

4.7.3 Further separation of toxic fraction 103

4.7.4 Tlc studies on fractions

5. DISSCUSSION

6. REFERENCE 


\section{LIST OF TABLES}

Page No

Table - 2.1 Distribution of palmyrah trees in Sri Lanka 8

Table-2.2 Composition of odiyal flour 11

Table - 2.3 Microelement composition of odiyal flour 12

Table - 2.4 The Amino acid composition of odiyal flour 13

Table - 2.5 The metal ion content of odiyal flour 14

Table-2.6 Antimicrobial effect of palmyrah flour 30

Table - 3.1 Composition of standard WHO rat/mice breeding feed 34

Table-4.1 Proximate composition of palmyrah flour 64

Table-4.2 Effect of $50 \%$ palmyrah flour on Wistar rats- variability of results 68

Table -4.3 Effect of $50 \%$ Palmyrah flour on ALT and AST levels 69

Table -4.4 Effect of toxicity according to locality 70

Table-4.5 Effect of extractive administration on body weight, 71 feed intake and ALT and AST levels

Table-4.6 Effect of washed and non-Washed palmyrah flour in "Pittu" on neurotoxicity

Table -4.7 Effect of using boiled palmyrah flour in palm posha on neurotoxicity 76

Table -4.8 Effect of heat treatment on neurotoxicity 77

Table-4.9 Effect of fractions on neurotoxicity 80

Table-4.10 Effect of fractions on time of appearance of symptoms 103

Table-5.1 Characters of the toxin 


\section{LIST OF FIGURES}

Page No

Figure - 2.1 Structure of flabelliferin aglycone 19

Figure-2.2 A novel triterpene (Dammarane) 20

Figure - 3.1 Summary of bio-directed fractionation 51

Figure - 3.2 D.Waldi's scheme 62

Figure - 4.1 Diagramatic representation of compound distribution on Tlc 105 


\section{LIST OF PLATES}

Page No

Plate $-2.1 \quad$ A photograph of palmyrah tree/s 2

Plate-2.1 A photograph of palmyrah soot 3

Plate-3.1 A photograph of Wistar rats 45

Plate-3.2 A photograph of MPLC set up

Plate $-4.1 \quad$ Liver of $50 \%$ palmyrah feed (Heated at $80^{\circ} \mathrm{C}$ )

fed rats $(\mathrm{H} \&$ E staining $\mathrm{x} 400)$

Plate -4.2 Liver of $50 \%$ palmyrah feed (Heated at $40^{\circ} \mathrm{C}$ )

fed rats showing hydropic degeneration of centrilobular cells ( $\mathrm{H} \&$ E staining x 400)

Plate - 4.3 Liver of control feed fed rats ( $\mathrm{H} \& \mathrm{E}$ staining $\mathrm{x} 400$ ) 84

Plate -4.4 Liver of $50 \%$ palmyrah feed (Heated at $80^{\circ} \mathrm{C}$ ) 85

fed rats (Fat staining $\times$ 400)

Plate -4.5 Liver of $50 \%$ palmyrah feed (Heated at $40^{\circ} \mathrm{C}$ ) 86 fed rats showing periportal fatty degeneration (Fat staining $\mathrm{x} 400$ )

Plate - 4.6 Liver of control feed fed rats (Fat staining $x$ 400)

Plate -4.7 Cerebrum of $50 \%$ palmyrah feed (Heated at $80^{\circ} \mathrm{C}$ ) fed rats ( $\mathrm{H} \&$ E staining $x$ 400)

Plate -4.8 Cerebrum of $50 \%$ palmyrah feed (Heated at $40^{\circ} \mathrm{C}$ ) fed rats ( $\mathrm{H} \&$ E staining $\mathrm{x} 400$ ) 
Plate - 4.9 Cerebrum of control feed fed rats (H \& E staining x 400) 90

Plate -4.10 Cerebellum of $50 \%$ palmyrah feed (Heated at $80^{\circ} \mathrm{C}$ ) 91

fed rats $(\mathrm{H} \&$ E staining $\times 400)$

Plate -4.11 Cerebellum of $50 \%$ palmyrah feed (Heated at $40^{\circ} \mathrm{C}$ ) 92

fed rats ( $\mathrm{H} \&$ E staining $\times 400)$

Plate-4.12 Cerebellum of control feed fed rats (H \& E staining x 400) 93

Plate -4.13 Spinal cord of $50 \%$ palmyrah feed (Heated at $80^{\circ} \mathrm{C}$ ) 94

fed rats $(\mathrm{H} \& \mathrm{E}$ staining $\mathrm{x} 400)$

Plate - 4.14 Spinal cord of 50\% palmyrah feed (Heated at $\left.40^{\circ} \mathrm{C}\right) \quad 95$

fed rats $(\mathrm{H} \&$ E staining $\times 400)$

Plate - 4.15 Spinal cord of control feed fed rats (H \& E staining x 400) 96

Plate -4.16 Cerebrum of $50 \%$ palmyrah feed (Heated at $80^{\circ} \mathrm{C}$ ) 97

fed rats (Fat staining x 400)

Plate -4.17 Cerebrum of $50 \%$ palmyrah feed (Heated at $40^{\circ} \mathrm{C}$ ) 98

fed rats showing periportal fatty degeneration

(Fat staining $\times$ 400)

Plate - 4.18 Cerebrum of control feed fed rats (Fat staining x 400) 99

Plate-4.19 Spinal cord of $50 \%$ palmyrah feed (Heated at $\left.80^{\circ} \mathrm{C}\right) \quad 100$

fed rats (Fat staining $x$ 400)

Plate-4.20 Spinal cord of 50\% palmyrah feed (Heated at $40^{\circ} \mathrm{C}$ ) 101

fed rats (Fat staining $\times$ 400)

Plate-4.21 Spinal cord of control feed fed rats (Fat staining x 400) 102 


\section{ABBREVIATIONS}

PFP Palmyrah Fruit Pulp

MPLC Medium Pressure Liquid Chromatography

Tlc Thin Layer Chromatography

AOAC Association of Official Analytical Chemists

AST Aspartate Aminotransferase

ALT Alanine Aminotransferase

WHO World Health Organization

PMA Phospho Molybdic Acid

DRG Dragendrof Reagent

PDB Palmyrah Development Board

H\&E Haematoxylin and Eosin

$\Delta \mathrm{A} \quad$ Absorbance difference

F-I Flabelliferin tertraglucoside in Kalpitiya

F-II Bitter flabelliferin tetraglycoside

$\mathrm{F}_{\mathrm{B}} \quad$ Anti- microbial flabelliferin triglycoside

$\mathrm{F}_{\mathrm{C}} \quad$ Inactive flabelliferin triglycoside

F D $\quad$ Flabelliferin diglycoside

$\mathrm{F}_{\mathrm{E}} \quad$ Flabelliferin diglycoside

$\mathrm{F}_{\mathrm{F}} \quad$ Flabelliferin diglycoside

$\mathrm{R}_{\mathrm{f}} \quad$ Retardation factor

Kg Kilogram 


$\begin{array}{ll}\text { UV } & \text { Ultra Violet } \\ \mathrm{ml} & \text { Millilitre } \\ { }^{\circ} \mathrm{C} & \text { Centigrade } \\ \mathrm{MW} & \text { Molecular Weight } \\ \mathrm{l} & \text { Litres } \\ \mathrm{ICR} & \text { Institute of Cancer Research } \\ \mathrm{DNS} & 3^{\mid} 5^{\mid} \text {Dinitro Salicylic Acid } \\ \mathrm{g} & \text { Grams } \\ \mathrm{IU} \mathrm{m} \mathrm{l}^{-1} & \text { International Units per millilitre } \\ \mathrm{min} & \text { Minutes } \\ \mathrm{h} & \text { Hour }\end{array}$




\section{ACKNOWLEDGEMENTS}

I take this opportunity to offer my deepest gratitude to my supervisor Professor Errol R. Jansz (Head of the Department, Department of Biochemistry, Faculty of Medical Sciences, University of Sri Jayewardenepura), for his never-tiring supervision, invaluable suggestions, proper guidance, inspiration and understanding throughout my research programme. I am eternally grateful to him for his invaluable contribution towards my success.

I extent heartfelt gratitude to my supervisor Professor S. M. D. N. Wickaramasinghe (Department of Biochemistry, Faculty of Medical Sciences, University of Sri Jayewardenepura), for her invaluable advice, instruction, supervision and constructive criticism during the period of my study.

I am ever indebted to Dr. S. Jayesekara (Veterinary Surgeon, Animal Section, Medical Research Institute), for providing facilities, invaluable advice, guidance and spending valuable time during animal studies.

I express gratitude to Professor N. Rantnatunge (Head of the Department, Department of Pathology, University of Peradeniya), for providing facilities, guidance and invaluable advice for my hitopathology work.

I offer my gratitude to Dr. .M. G. Thammitiyagoda (Veterinary Surgeon, Animal Section, Medical Research Institute), for her sincere encouragement throughout my course of study. I also owe my thanks to Mr. J. K. Nikawala for providing palmyrah flour as required for the successful completion of the research. 
My special thanks go to Mrs. Jayasinghe (Manager, Agro Food Technology Division, Industrial Technology Division), for providing facilities to conduct Kjeldhal method.

I acknowledge with thanks Miss. S. Ramadasa (Laboratory technician, Department of Pathology, University of Peradeniya).

I acknowledge the contribution of the staff of Biochemistry (Faculty of Medical Sciences, University of Sri Jayewardenepura), staff of the Animal Section (Medical Research Institute) and all those who worked with me in the laboratory extending their kind cooperation towards my research study.

Financial assistance provided by Palmyrah Development Board (PDB) and International Programme in Chemical Sciences (IPICS SRI :07) are acknowledged.

Finally, my gratitude is hereby offered to my dear parents, sister, brother and dearest husband for their constant support and encouragement extended throughout this study and this is dedicated to them. 


\section{SOME FACTORS AFFECTING THE NEUROTOXIC EFFECT OF PALMYRAH FLOUR}

\section{KURUWITA ARACHCHIGE VINDIKA SUMUDUNIE}

\section{ABSTRACT}

Since 1971 , many toxicities have been reported in animal studies particularly using Wistar rats fed on unboiled palmyrah flour (odiyal). The studies mainly contained reports on neurotoxicity and hepatotoxicity. In an attempt to duplicate pioneer studies done in 1971 with Wistar rats, showed that the animals did not consume $100 \%$ flour. Therefore the studies were commenced using a mixture of WHO recommended rat feed and palmyrah flour (50:50 and 30:70). Neurotoxic symptoms were visible within five days. This was accompanied by an elevation of AST $(p=0.040)$ but not an elevation in ALT $(p=0.396)$. Studies showed that toxicity varied from site of sampling (Kalpitiya $>$ Mannar $>$ Jaffna). Further, Wistar rats (effect shown in 5 days) seemed to be affected before than ICR mice (symptoms in 8 days). The symptoms were the same as those observed in the past studies, such as ruffled coat, muscle incoordination, characteristic fits, coordinated spasms, falling over backwards, immobility of hind limbs, and finally death. In addition to this, it was observed in this study that the animals were subject to hyper-excitation to touch and pharaphymosis.

The next part of the study was to determine how palmyrah flour could be detoxified. The flour from boiled Kottaikilengu (Plukodiyal) or other wet heat processes (steaming) did not 
eliminate the toxicity. Although the toxin is very soluble in water, washing of odiyal did not eliminate toxicity, but rather reduced it. These studies were conducted using traditional palmyrah food processing methods. However dry heat at $80^{\circ} \mathrm{C}$ for 45 min removed the toxicity (both hepatotoxicity/ neurotoxicity). Hepatotoxicity was judged by histopathology on liver by Haematoxylin \& Eosin staining and Oil Red O' staining. There was periportal fatty degeneration and hepatocellular hydropic degeneration at $40^{\circ} \mathrm{C}$ heat treatment on light microscopy but not in the $80^{\circ} \mathrm{C}$ treated sample.

The water extract of palmyrah flour produced neurotoxic symptoms, hepatotoxic symptoms (histopathology) and elevation of AST value to 104.3 $\pm 23.1 \quad(p=0.0261)$. However methanol extract did not extract the toxin. The water: methanol extract showed only sub-clinical symptoms and AST value $95.5 \pm 22.9,(p=0.044)$

The next line of the study was to purify the toxin. Fold purification by Medium Pressure Liquid Chromatography was 375. The activity appeared only in the water fraction. Although the dose was theoretically high, the unabsorbed eluate obtained from cation exchange resin showed neurotoxic effects in very low intensities. This indicated that either some of the toxin is lost during separation or both fractions (unabsorbed and absorbed) should be present giving a synergistic effect. Thin layer chromatography of the toxic fraction showed spots at $\mathrm{R}_{\mathrm{f}}=0.15$ in addition to the normal sugars of palmyrah. The spot at the $R_{f} 0.15$ was absent in the non-toxic fraction. It appears possible that this may be one of the compounds that contribute to toxicity.

The histopathology of rats provided evidence for toxicity to the liver and this would explain the hepatotoxic effect. Other workers had shown that the mitochondria are 
affected. This will explain the elevation of AST levels but not ALT levels. No lesions in the brain or spinal cord were observed when viewed macroscopically. It is hypothesized that the toxin is a mitochondrial toxin that gives both the hepatotoxic effect and the neurotoxic effects as both the muscle and the nerve have the highest number of mitochondria that would be one explanation for the neurotoxic effect. However, this could not be confirmed due to the non-availability of electron microscopy to show mitochondrial damage in muscle and nerve tissue. Another interpretation is that the neurotoxic effect is an extreme manifestation of the hepatotoxic effect. Whatever the case it seems that the neurotoxin and hepatotoxin are whole or part of the same molecule. This explanation requires that the neurotoxic effect is a result of the hepatotoxic effect; brought about as a result of mitochondrial damage to liver mitochondria, which could affect many pathways including the urea cycle. 